\title{
The Health Effects of Strongyloidiasis on Pregnant Women and Children: A Systematic Literature Review
}

\author{
Matthew Paltridge * (D) and Aileen Traves \\ College of Medicine and Dentistry, James Cook University, Smithfield QLD 4878, Australia; \\ Aileen.Traves@jcu.edu.au \\ * Correspondence: matthew.paltridge@my.jcu.edu.au; Tel.: +61-400-872-750
}

Received: 28 April 2018; Accepted: 15 May 2018; Published: 18 May 2018

\begin{abstract}
Strongyloidiasis is a helminth infection that remains under-researched despite its ability to cause significant illness. Women and children may be at particular risk of health consequences from this parasite. This systematic literature review aims to examine research on the long-term health effects that strongyloidiasis has in pregnant women and children. We conducted a structured search using multiple databases to collect all primary studies discussing health effects of strongyloidiasis in the aforementioned groups. The review included 20 results: 16 primary studies and four case reports. The methodological quality of studies was substandard, and there was substantial heterogeneity to the statistical analysis and outcomes assessed in the literature. Statistically significant associations were found between strongyloidiasis and low birth weight, as well as wasting. No links were found between strongyloidiasis and anaemia. Due to testing methods used in the studies, the prevalence of Strongyloides stercoralis in these studies was probably under-estimated. Current research is suggestive that strongyloidiasis has long-term adverse health effects on the offspring of infected mothers and in chronically-infected children. Data analysis was hindered by both methodological and statistical flaws, and as such, reliable conclusions regarding the health impacts could not be formed.
\end{abstract}

Keywords: Strongyloidiasis; low birth weight; wasting

\section{Introduction}

Strongyloidiasis is a Neglected Tropical Disease (NTD) caused by the infection of a host with the soil-transmitted nematode of the Strongyloides genus. Humans are most commonly infected by S. stercoralis. However, S. fuelleborni has also been observed to infect humans in Papua New Guinea (PNG). S. stercoralis is believed to infect over 370 million people worldwide [1].

Strongyloidiasis was originally identified as a disease to look for primarily in returned travellers, refugees, or war veterans [2,3]. The life cycle of $S$. stercoralis grants it the ability to autoinfect hosts, thereby allowing the parasites to persist chronically in individuals. The parasite was believed to exist in the small intestines of hosts in a predominantly asymptomatic state, but it occasionally caused low-grade epigastric pain and diarrhoea. Studies have instead shown that intermittently symptomatic strongyloidiasis is more common than asymptomatic infection [4]. As more precise serological tests are being developed, recent data is showing that the prevalence of Strongyloides infections remains consistently underestimated [2,5].

There are a variety of testing methods currently utilised to detect $S$. stercoralis infection. However, they differ greatly in their accuracy [6]. The current gold standard as recognised by the Centers for Disease Control and Prevention (CDC) is seven stool samples using specialised testing techniques such as the Baermann concentration or nutrient agar plate cultures [7]. While studies typically relied on stool samples, modern serological techniques have been proven to be more accurate and practical for use in research [8]. 
Strongyloidiasis has also been associated with life-threatening illness. Immunosuppression allows the parasite to multiply rapidly in the small intestine and migrate through the gut to the bloodstream and other organs. This is called disseminated strongyloidiasis (DS) or hyperinfection syndrome (HS), which has a mortality rate of $85-100 \%$ from overwhelming sepsis [9]. Common conditions that cause adequate immunosuppression include HTLV-1 infection, malignancy, and exogenous corticosteroid administration [10].

While researchers have been able to shed light on the acute health effects of strongyloidiasis, the long-term consequences of this infection have not yet been fully identified. One of the main hypothesised chronic effects of strongyloidiasis is malnutrition; however, there is insufficient evidence to be certain. Milner et al. have postulated a model by which malabsorption occurs in S. stercoralis-infected patients, where the infection causes oedema and inflammation of the small intestine walls and prevents nutrient uptake [11]. While this is an old study that has struggled to be replicated in similar projects, a theoretical mechanism of malabsorption exists for S. strongyloides, suggesting that the parasite may well lead to malnutrition [12]. If this is the case, chronic strongyloidiasis has a direct clinical relevance to particular sub-groups of society that are most susceptible to harm from malnutrition, such as pregnant women, infants, and children.

Pregnant women are most likely to be affected by strongyloidiasis through two mechanisms: acute severe infection due to immunosuppression, or chronic nutritional deficiencies. Physiological changes during pregnancy cause a level of immunosuppression in the mother, placing her at an increased risk of HS or DS $[13,14]$. While pregnancy alone has not been observed to cause severe strongyloidiasis, corticosteroids are often administered to women when clinicians suspect a preterm delivery, and this combined effect may immunosuppress the mothers sufficiently to cause severe infection [15]. Some parasitic infections have also been known to cause anaemia during pregnancy, and theoretically $S$. stercoralis may do the same $[16,17]$.

When looking at the risks to pregnant women, the risks to their unborn fetuses must also be considered. The offspring of infected mothers may be placed at an increased risk of harm from the effects of maternal malnutrition. Multiple studies have researched whether maternal helminth infections are a risk factor for poor pregnancy outcomes, such as intra-uterine growth restriction (IUGR) or low birth weight (LBW). While there is evidence to suggest that this may be the case, it remains unsubstantiated [18-21]. Helminth genera such as Ascaris or Ancylostoma tend to be the focus of such studies; thus there is insufficient literature to demonstrate whether strongyloides does or does not contribute to LBW as well. This is an important gap in knowledge, because if strongyloidiasis does in fact lead to LBW, this means that clinicians are not appropriately screening and treating populations in endemic areas.

Children more generally may also be affected if they become chronically infected during their childhood. Chronic diseases in childhood that produce poor growth are a particular public health concern due to the long term multifactorial consequences they have on individuals and society [22,23]. If strongyloides does cause malabsorption, this will affect the growth and development of children and leave them at an increased risk of poor health outcomes later in life. Insufficient literature is available to determine whether this is the case.

As an NTD, there is a lack of adequate research analysing the effects of strongyloides. Very few studies mention the specific consequences for pregnant women and children, and no systematic reviews have been performed studying the chronic health effects of strongyloidiasis. Those studies that do discuss chronic harm present enough theoretical and observational evidence to hypothesise that there are major health impacts on these sub-groups of the population, justifying the need for a more expansive review of the literature. This review aims to systematically summarise current evidence on the long-term effects that chronic strongyloidiasis has on pregnant women, their offspring, and infected children in general. By doing so, we hope to determine whether these sub-groups are at a potentially higher risk of harm than the rest of the population and highlight current gaps in research. 


\section{Materials and Methods}

This systematic literature review was conducted and reported according to the Preferred Reporting Items for Systematic Reviews and Meta-Analyses (PRISMA) guidelines (Appendix A) [24]. The review focuses on primary studies that measured the health outcomes of strongyloides infections in pregnant women, the offspring of infected women, and children who were chronically infected during their childhood. The review has been structured according to the 'Narrative Synthesis' format described by Mays et al., for ease of reading and in order to easily draw conclusions between studies with different objectives and designs [25]. The review was registered with the PROSPERO International Prospective Register of Systematic Reviews (ID: CRD42017069403). Specific questions this review attempts to answer include: what are the current acute and chronic health effects that strongyloidiasis poses to these cohorts, and, what gaps remain in the literature studying chronic strongyloidiasis?

\subsection{Search Strategy}

The search strategy was based on the database sources of Medline, PubMed, CINAHL, Web of Science, Informit, The Cochrane Collaboration, Scopus, and Google Scholar. A subsequent snowball search of the reference lists of included full text articles was conducted to find further relevant sources. References were stored using EndNote $\mathrm{X} 8^{\mathrm{TM}}$.

The search strategy was centred around six key concepts highlighted in Table 1: 'strongyloidiasis', 'severe disease', 'pregnancy', 'infant', 'immune status', and 'eosinophilia'. 'Severe disease' was defined as any disease classified in the article as disseminated strongyloidiasis (DS) or hyperinfection syndrome (HS). Pregnancy included the presence of a live fetus at any week of gestation. 'Immune status' was used to find references to immunosuppressed populations in which strongyloidiasis may occur, such as HIV or HTLV1-infected cohorts.

Table 1. Concepts and synonyms used in search strategy.

\begin{tabular}{ccl}
\hline$\#$ & \multicolumn{1}{c}{ Concept } & \multicolumn{1}{c}{ Key Words } \\
\hline 1 & Strongyloidiasis & Strongyl * OR Anguillulose \\
\hline 2 & Severity of disease & $\begin{array}{l}\text { Disseminat * OR Hyperinfect * OR Severe OR Fatal OR Mortality } \\
\text { OR Morbidity OR Death * }\end{array}$ \\
\hline 3 & Pregnancy & $\begin{array}{l}\text { Pregnan * OR Mother * OR Matern * OR Antenat * OR Natal } \\
\text { OR Perinat * }\end{array}$ \\
\hline 4 & Infant & $\begin{array}{l}\text { Neonat * OR Newborn OR Infant * OR Baby * OR Fetus * OR } \\
\text { Foetus * OR Fetal OR Preterm OR Child OR Prematur * OR Low } \\
\text { Birth Weight OR LBW OR Birth Weight OR Intrauterine Growth } \\
\text { Restriction OR IUGR OR FGR OR SGA }\end{array}$ \\
\hline 5 & Immune status & $\begin{array}{l}\text { Immunocompromised OR Tumour OR Cancer OR Haematolog * } \\
\text { OR Lymphom * OR Leukaem * OR Neoplas * OR Malignan * OR } \\
\text { HIV OR HTLV1 OR Rheumat * OR Diabet * OR Transplant * OR } \\
\text { Steroid * OR Corticosteroid * OR Immunosuppress * OR } \\
\text { Glucocorticoid * OR Sepsis }\end{array}$ \\
\hline 6 & Eosinophilia & Eosin * \\
\hline
\end{tabular}

* keywords were truncated with asterisks added, to locate all forms of the word during the literature search.

Synonyms were drafted with the help of other strongyloidiasis-related literature reviews $[6,26,27]$. Search terms were modified to fit with the search requirements of each database used, including the use of MeSH terms for PubMed. Literature searching commenced on 26 July 2017 and was completed on 9 August 2017. The full search strategy outlining the combinations of terms used is depicted in Table 2. 
Table 2. Combinations of key words used in search strategy.

\begin{tabular}{cc}
\hline Number Search & Combination \\
\hline 1. & $1+3$ \\
2. & $1+6$ \\
3. & $1+2+3$ \\
4. & $1+2+6$ \\
5. & $1+3+4$ \\
6. & $1+3+5$ \\
7. & $1+3+6$ \\
8. & $1+4+6$ \\
9. & $1+5+6$ \\
\hline
\end{tabular}

\subsection{Data Collection and Analysis}

Titles and then abstracts were screened for potential inclusion. The full texts were then read to determine their eligibility according to the search criteria. If the full text could not be found, attempts were made to contact the authors or other institutions to access a full text. Articles that met the criteria were included for analysis.

A standardised spreadsheet was used to extract data from the full text articles. Data items obtained included study date, sample size, country, funding sources, ethics approval, characteristics of participants, outcomes measured, method of testing for S. stercoralis, statistical analysis performed, prevalence of strongyloidiasis, eosinophilia, limitations or confounding factors, and results of outcomes measured. Thematic analysis involving the simple pooling of data items was performed. Included studies and their data points were presented in both individual and aggregated tables. Due to the articles being primarily observational studies with a heterogeneous range of outcomes studied, meta-analysis was not performed.

\subsection{Inclusion Criteria}

We included all quantitative studies that tested for Strongyloides infections in cohorts of pregnant women, newborns, or children aged 0 to 18 years of age. If the study cohort focused on children, articles were only included if they measured the long-term effects on participants. Articles were included regardless of what outcomes they measured, such as haemoglobin $(\mathrm{Hb})$ levels, neurocognitive function, or anthropometry. Types of research that were included in this review consisted of randomised control trials, observational studies, and individual case reports. Case reports were included due to the limited results that we found in our scoping searches prior to the formal literature search. By including case reports on top of the more rigorous primary literature, we can present a full landscape of current studies of strongyloidiasis in pregnant women and children.

\subsection{Exclusion Criteria}

Epidemiological studies that only commented on risk factors for infection (rather than outcomes) were excluded. Animal studies were excluded as no studies specifically looking at strongyloidiasis in pregnant animals were identified. Conference proceedings, poster presentations, and abstracts without a full text were also excluded. No language restrictions or date ranges were placed on included texts.

We hypothesised that there would be very little literature discussing srongyloidiasis in pregnant women and their children, and that many of the studies may have suboptimal methodological quality. As such, we did not exclude studies based on their methodology or statistical analysis used, as if they were found to be of generally poor quality, this would be an important limitation of current research to discuss. 


\subsection{Methodological Quality}

A quality assessment of the observational studies was conducted according to a scale specifically generated for this review (Table 3). The scale is a modification of previously validated tools and used criteria from the Quality Appraisal for Cadaveric Studies (QUACS) scale first used by Smith et al., the Newcastle-Ottawa Scale (NOS), and an independent scale used in a similar systematic literature review [28-30]. QUACS and NOS have been validated as accurate tools to use in observational studies; however, specific items were added to the scale to make it more applicable for assessing the studies included in this review [31]. Due to the heterogeneous nature of methodologies and results used, we refrained from providing a score to assess and compare quality.

Table 3. Quality assessment tool used for observational studies.

\begin{tabular}{|c|c|c|c|}
\hline & Low Risk & Medium Risk & High Risk \\
\hline Objective stated & $\begin{array}{l}\text { Aims and objectives } \\
\text { fully described with } \\
\text { reasons for why they } \\
\text { are important }\end{array}$ & $\begin{array}{l}\text { Aims and objectives } \\
\text { described, no reasons } \\
\text { given for having } \\
\text { these aims }\end{array}$ & $\begin{array}{l}\text { Aims and objectives } \\
\text { not fully described }\end{array}$ \\
\hline Ethics and funding & Mentioned, no conflicts & $\begin{array}{l}\text { Mentioned, potential } \\
\text { conflicts of interest }\end{array}$ & $\begin{array}{l}\text { Not mentioned or } \\
\text { conflicts of interest }\end{array}$ \\
\hline Methods described & $\begin{array}{l}\text { Methods discussed and are } \\
\text { reliable }\end{array}$ & $\begin{array}{l}\text { Methods discussed, } \\
\text { but may not be reliable }\end{array}$ & $\begin{array}{l}\text { Methods not fully } \\
\text { discussed }\end{array}$ \\
\hline Details context of group & $\begin{array}{l}\text { Participant characteristics } \\
\text { outlined with discussion of } \\
\text { how an accurate sample } \\
\text { was ensured }\end{array}$ & $\begin{array}{l}\text { Participant } \\
\text { characteristics outlined }\end{array}$ & $\begin{array}{l}\text { Participant } \\
\text { characteristics not } \\
\text { fully outlined }\end{array}$ \\
\hline $\begin{array}{l}\text { Inclusion criteria, } \\
\text { exclusion criteria, } \\
\text { sample size }\end{array}$ & $\begin{array}{l}\text { Fully described with } \\
\text { reasons given }\end{array}$ & Fully described & $\begin{array}{l}\text { Not adequately } \\
\text { described }\end{array}$ \\
\hline Education of researchers & $\begin{array}{l}\text { Education given, } \\
\text { researchers have } \\
\text { appropriate experience } \\
\text { or qualifications }\end{array}$ & $\begin{array}{l}\text { Education given, } \\
\text { experience or } \\
\text { qualifications not } \\
\text { mentioned }\end{array}$ & $\begin{array}{l}\text { Education and } \\
\text { experience is not } \\
\text { discussed }\end{array}$ \\
\hline $\begin{array}{l}\text { Methodological bias } \\
\text { discussed and addressed }\end{array}$ & $\begin{array}{l}\text { Efforts made to identify } \\
\text { and solve potential bias }\end{array}$ & $\begin{array}{l}\text { Mention of potential bias } \\
\text { in methodology }\end{array}$ & $\begin{array}{l}\text { No mention of bias } \\
\text { in methodology }\end{array}$ \\
\hline More than one researcher & More than one researcher & $\mathrm{N} / \mathrm{A}$ & Only one researcher \\
\hline $\begin{array}{l}\text { Statistical analysis } \\
\text { appropriate }\end{array}$ & $\begin{array}{l}\text { Multivariate logistic } \\
\text { regression is used }\end{array}$ & $\begin{array}{l}\text { Chi square analysis } \\
\text { is used }\end{array}$ & $\begin{array}{l}\text { Any other form of } \\
\text { analysis is used }\end{array}$ \\
\hline $\begin{array}{l}\text { Results presented } \\
\text { thoroughly }\end{array}$ & $\begin{array}{l}\text { Results fully and } \\
\text { accurately described }\end{array}$ & Only partial results given & $\begin{array}{l}\text { Important results } \\
\text { omitted or not } \\
\text { thoroughly described }\end{array}$ \\
\hline $\begin{array}{l}\text { Study discussed in } \\
\text { context }\end{array}$ & $\begin{array}{l}\text { Results analysed according } \\
\text { to other studies }\end{array}$ & $\begin{array}{l}\text { Results are analysed, } \\
\text { some mention of } \\
\text { current context }\end{array}$ & $\begin{array}{l}\text { Results analysed } \\
\text { with no mention to } \\
\text { other research }\end{array}$ \\
\hline $\begin{array}{l}\text { Clinical implications } \\
\text { of results }\end{array}$ & $\begin{array}{l}\text { Direct clinical application } \\
\text { of results is discussed }\end{array}$ & $\begin{array}{l}\text { Mention of clinical } \\
\text { relevance is made }\end{array}$ & $\begin{array}{l}\text { No mention of clinical } \\
\text { implications of results }\end{array}$ \\
\hline $\begin{array}{l}\text { Limitations and } \\
\text { confounding factors }\end{array}$ & $\begin{array}{l}\text { Study discussed } \\
\text { limitations and } \\
\text { confounding factors } \\
\text { comprehensively }\end{array}$ & $\begin{array}{l}\text { Some discussion of } \\
\text { limitations and } \\
\text { confounding factors }\end{array}$ & $\begin{array}{l}\text { No discussion of } \\
\text { limitations or } \\
\text { confounding factors }\end{array}$ \\
\hline
\end{tabular}

N/A: not applicable.

Case series were assessed for quality according to the Joanna Briggs Institute Critical Appraisal Tool: Checklist for Case Reports [32]. The risk of bias evaluations was not used to exclude studies from data synthesis but rather would be utilised to comment on the current gaps in literature and accuracy of results. 


\section{Results}

Database and reference list searching returned 1666 unique results, of which 94 were considered eligible for full-text review. The full texts of 29 sources could not be found, even after attempts were made to contact authors, libraries, and institutions to access a copy. These studies were decades old, focused on other parasites, and from the citation information available did not indicate that they would add further use to this review or significantly change the conclusions. This left 65 full-text articles that were read in full. Based on our inclusion and exclusion criteria, 45 articles were then excluded. Thirty-nine full texts were excluded as they were either found to be irrelevant or were solely epidemiological studies and did not measure health outcomes of their participants. Six studies were found to be review articles and were subsequently excluded. This left a total of 20 studies for inclusion.

Sixteen articles were sourced from electronic library databases, while the remaining four studies were individually added from the Google Scholar search; no further articles were added after reviewing the reference lists of included full-texts. Sixteen studies were original research papers while four articles were individual case reports that discussed Strongyloides in pregnant women. Countries in which studies were performed included Australia (1), France (1), Ghana (2), Guatemala (1), India (1), Kenya (1), Nigeria (1), Papua New Guinea (3), Peru (2), Tanzania (1), Thailand (2), Uganda (2), Unites States of America (USA, 2) and Venezuela (1). Publication dates of the articles ranged from 1989 until 2015. The outcomes of the search strategy are summarised in Appendix B. For the purpose of clarity, the research papers will be discussed separately to the case studies.

\subsection{Study Characteristics}

Participant demographics included pregnant women (3), pregnant women and their newborn children (5), or only infected children (8). Participants were mostly from low socio-economic environments, and hygiene was typically stated as poor in the studies. Only one study focused specifically on $S$. stercoralis infections, and two studies focused on S. fuelleborni. The majority of studies either surveyed all helminth infections in their cohorts, or their main focus was on other helminths, malaria, or HIV, and happened to include data on strongyloidiasis. The study settings included in-hospital environments (3), community settings (10), or antenatal and postnatal clinics (3) (Table 4).

\subsection{Quality Assessment}

Overall, the methodological rigour of the literature was of a low quality. With regard to the prospective studies, 16 were cohort studies while only one was a case-control study; there were no randomised controlled trials included. The studies were found to vary widely in their study designs, attempts to control bias, and outcomes measured (Appendix C, Figure A3).

Nine studies used logistic regression, while five studies use chi-square analysis. The majority of studies did not consider or report potential bias being present in their studies and took limited steps to prevent this from affecting their results. Many studies did not adequately discuss their inclusion and exclusion criteria, sample sizes, or the involvement of researchers in data collection. The cohorts were often arbitrarily chosen and not adequately matched. Many of the studies were quoted to be using data from other larger trials without discussing any potential bias in these results. The majority of studies only reported data selectively and did not specify the non-significant results.

Case reports were overall of a high quality and comprehensively discussed the clinical relevance of their patients (Appendix C, Figure A4).

\subsection{Risk of Bias of Included Studies}

Generally, the literature did not appropriately comment on potential limitations or confounding factors to their research. Some commonly mentioned limitations amongst studies included small sample sizes, small prevalence data of $S$. stercoralis, inappropriate testing methods, and inability to follow-up with included participants. 
Table 4. Study Characteristics.

\begin{tabular}{|c|c|c|c|c|c|c|}
\hline Author, Year, Country & Study Design & Participant Characteristics & Sample Size & Length of Review & Setting & Prevalence \\
\hline Baidoo et al., (2010), Ghana [33] & $\begin{array}{c}\text { Prospective observational } \\
\text { cohort study }\end{array}$ & Pregnant women & 108 & 12 months & Community & $2 \%$ \\
\hline Barnish et al., (1989), Papua New Guinea [34] & $\begin{array}{c}\text { Prospective observational } \\
\text { cohort study }\end{array}$ & Children $<5$ years & 12 & NR & Community & $63 \%$ \\
\hline Cabada et al., (2014), Peru [35] & $\begin{array}{c}\text { Prospective observational } \\
\text { cohort study }\end{array}$ & $\begin{array}{l}\text { Amazonian clan members, } \\
\text { all ages }\end{array}$ & 215 & NR & Community & $6 \%$ \\
\hline Mangklabruks et al., (2012), Thailand [36] & $\begin{array}{c}\text { Prospective observational } \\
\text { cohort study }\end{array}$ & $\begin{array}{l}\text { Newborns followed from } \\
\text { antenatal clinic visits }\end{array}$ & 2184 & 1 year 9 months & $\begin{array}{c}\text { Antenatal and } \\
\text { postnatal clinics }\end{array}$ & $0.8 \%$ \\
\hline Dada-Adegbola et al., (2004), Nigeria [37] & $\begin{array}{c}\text { Prospective observational } \\
\text { cohort study }\end{array}$ & $\begin{array}{c}\text { Children }<5 \text { years } \\
\text { with diarrhoea }\end{array}$ & 227 & NR & Hospital & $5.3 \%$ \\
\hline Dreyfuss et al., (2001), Tanzania [38] & $\begin{array}{c}\text { Prospective observational } \\
\text { cohort study }\end{array}$ & $\begin{array}{l}\text { HIV-infected pregnant } \\
\text { women and their newborns }\end{array}$ & 822 & NR & $\begin{array}{c}\text { Antenatal and } \\
\text { postnatal clinics }\end{array}$ & $1.78 \%$ \\
\hline Egger et al., (1990), Thailand [39] & $\begin{array}{c}\text { Prospective observational } \\
\text { cohort study }\end{array}$ & Children $3-8$ years & 343 & NR & Community & $25.4 \%$ \\
\hline Herrera et al., (2006), Peru [40] & $\begin{array}{c}\text { Prospective observational } \\
\text { case-control study }\end{array}$ & $\begin{array}{c}\text { Community members } \\
<20 \text { years }\end{array}$ & 100 & 1 month & Community & NR \\
\hline King et al., (2004), Papua New Guinea [41] & $\begin{array}{c}\text { Prospective observational } \\
\text { cohort study }\end{array}$ & Children $<5$ years & 179 & 4 months & Community & $27 \%$ \\
\hline LaBeaud et al., (2015), Kenya [42] & $\begin{array}{c}\text { Prospective observational } \\
\text { cohort study }\end{array}$ & $\begin{array}{c}\text { Mothers and their infants } \\
<3 \text { years }\end{array}$ & 545 & 3 years & Community & NR \\
\hline Muhangi et al., (2007), Uganda [43] & $\begin{array}{c}\text { Prospective observational } \\
\text { cohort study }\end{array}$ & Pregnant women & 2507 & 1 year 7 months & Hospital & $12.3 \%$ \\
\hline Nampijja et al., (2012), Uganda [44] & $\begin{array}{c}\text { Prospective observational } \\
\text { cohort study }\end{array}$ & $\begin{array}{l}\text { Mothers and their infants } \\
<15 \text { months }\end{array}$ & 983 & 2 years & $\begin{array}{c}\text { Antenatal and } \\
\text { postnatal clinics }\end{array}$ & $13 \%$ \\
\hline Phuanukoonnon et al., (2013), Papua New Guinea [45] & $\begin{array}{c}\text { Prospective observational } \\
\text { cohort study }\end{array}$ & Pregnant women & 201 & 1 year 5 months & Community & $3 \%$ \\
\hline Verhagen et al., (2013), Venezuela [46] & $\begin{array}{c}\text { Prospective observational } \\
\text { cohort study }\end{array}$ & Children $4-17$ years & 390 & 1 year 6 months & Community & $7.9 \%$ \\
\hline Villar et al., (1989), Guatemala [47] & $\begin{array}{c}\text { Prospective observational } \\
\text { cohort study }\end{array}$ & Mothers and their newborns & 14,914 & 1 year 9 months & Community & $0.4 \%$ \\
\hline Yatich et al., (2010), Ghana [48] & $\begin{array}{l}\text { Prospective observational } \\
\text { cohort study }\end{array}$ & Mothers and their newborns & 746 & 2 months & Hospital & $3.9 \%$ \\
\hline
\end{tabular}




\subsection{Prevalence}

The prevalence of $S$. stercoralis in the studies was typically low, with a mean prevalence of $12.3 \%$ and the median prevalence being $6 \%$. Studies with mixed urban and rural cohorts found that the prevalence of strongyloidiasis was higher in participants from rural areas. A few studies noted that their prevalence data was unreliable due to using suboptimal testing methods that have been proven to be inaccurate for detecting $S$. stercoralis [6].

\subsection{Method of Testing}

All the studies included in this review used various methods of stool-sample analysis to determine the rates of $S$. stercoralis infections in their cohorts. Methods included the Baermann (3 studies), Kato-Katz (4), Ritchie (1), formol-ether concentration (2), simple smear technique (1), volume dilution method (1), or were unspecified (4). No studies utilised serological testing. Single samples with limited follow-up were used, rather than the serial testing of multiple specimens.

\subsection{Effects on $L B W$}

Four studies measured the effect that $S$. stercoralis infection in pregnant women had on the birth weight of their offspring $[36,38,47,48]$. Two studies, one in Thailand and one in Tanzanian HIV-infected mothers, found odds ratios of 4.93 (95\% CI 1.47, 16.50) and 4.23 (95\% CI 1.24, 14.41), respectively, that LBW was caused by strongyloidiasis (Table 5) [36,38]. One study in Ghana found an odds ratio of 2.1 (95\% CI 0.97, 4.49) for LBW, small for gestational age (SGA), or preterm delivery [48]. The fourth study found a non-significant increased risk of IUGR; the study attributed a low prevalence of strongyloidiasis to the failure to achieve a statistically significant result [47]. IUGR was predominantly seen in malnourished women who had strongyloidiasis, and the study authors hypothesised this as a possible cause rather than the helminth itself. None of the studies measured the length of duration of S. stercoralis infection in the pregnant mother, or the intensity of larval output as an indicator of the severity of the infection.

\subsection{Anthropometry}

Five studies analysed whether there were long term effects of Strongyloides infections on the nutrition and growth of infected children (Table 6) [39-42,46]. Three studies found that strongyloidiasis was associated with decreased weight-for-height or weight-for-age z-scores. However, not all of these were statistically significant $[39,40,46]$. These measurements are more typically used to determine wasting, which is an acute indicator of malnutrition, rather than the more chronic indicator of stunting. One study found a statistically significant relationship between strongyloidiasis and decreased height-for-age z-score $(p<0.01)$, which is used to measure stunting [39]. One study found that at 30 months of age, children with strongyloidiasis had a decreased head circumference $(p=0.002)$; this same study did not find any significant link to other anthropometric measures. One study found no statistically significant relationships between stunting, wasting, and S. stercoralis infections, but did note that the intensity of infection was associated with decreased weight-for-age and weight-for-height z-scores, within the Strongyloides-infected population ( $p=0.02,0.016$ respectively) [41]. Another article found that children infected with strongyloidiasis were substantially more likely to suffer from marasmus or kwashiorkor when compared to non-infected children $(p=0.001)$ [40]. The majority of studies also found that polyparasitism was more strongly associated with lower z-scores of all the anthropometric measures when compared to solely S. stercoralis infection. 
Table 5. Methodology and outcomes of Strongyloides infections.

\begin{tabular}{|c|c|c|c|c|c|}
\hline Study & $\begin{array}{l}\text { Only S. stercoralis } \\
\text { Is Assessed }\end{array}$ & $\begin{array}{l}\text { Results Are } \\
\text { Aggregated }\end{array}$ & $\begin{array}{l}\text { Testing Method for } \\
\text { S. stercoralis }\end{array}$ & Statistical Analysis & Results \\
\hline 33 & No & Yes & $\begin{array}{l}\text { Stool; formol-ether } \\
\text { concentration method }\end{array}$ & Chi-square test & $\begin{array}{c}\text { Helminth infections are a predictor of iron-deficiency anaemia in } \\
\text { pregnant women }\end{array}$ \\
\hline 34 & No & No & Stool; not specified & Correlation coefficient & Heavy infection predisposes to poor growth \\
\hline 35 & No & No & Stool; Kato-Katz method & Chi-square test & $\begin{array}{l}\text { High rates of anaemia and malnutrition in children } \\
\text { Helminth infections not associated with these outcomes } \\
\text { Strongyloides was not managed by treatment }\end{array}$ \\
\hline 36 & No & Yes & Not specified & $\begin{array}{l}\text { Multivariate logistic } \\
\text { regression }\end{array}$ & $\begin{array}{c}\text { Odds ratio of } 4.93 \text { of Strongyloides / hookworm infection in pregnancy } \\
\text { causing LBW }(95 \% \text { CI } 1.47,16.50)\end{array}$ \\
\hline 37 & Yes & $\mathrm{N} / \mathrm{A}$ & $\begin{array}{l}\text { Stool; formol-ether } \\
\text { concentration methods }\end{array}$ & Logistic regression & $\begin{array}{l}\text { Higher rates of malnourished in Strongyloides-infected children } \\
\text { Malnutrition may increase the risk of contracting Strongyloides }\end{array}$ \\
\hline 38 & No & No & Stool; Kato-Katz method & $\begin{array}{l}\text { Multivariate logistic } \\
\text { regression }\end{array}$ & Odds ratio of 4.23 for Strongyloides causing LBW $(95 \%$ CI 1.24, 14.41) \\
\hline 39 & No & No & $\begin{array}{l}\text { Stool; simple smear } \\
\text { technique }\end{array}$ & Chi-square test & Lower mean height-for-age $\mathrm{z}$-score $(p<0.01)$ \\
\hline 40 & No & No & Stool; Baermann method & $\begin{array}{l}\text { Multivariate logistic } \\
\text { regression }\end{array}$ & $\begin{array}{l}\text { Malnutrition more common in Strongyloides infections } \\
\text { No relationship between Strongyloides and anthropometry }\end{array}$ \\
\hline 41 & No & No & $\begin{array}{l}\text { Stool; volume dilution } \\
\text { method }\end{array}$ & Logistic regression & $\begin{array}{c}\text { Strongyloides associated with decreased weight-for-age z-score }(p<0.05) \\
\text { Not associated with weight-for-height } z \text {-score }(p<0.05)\end{array}$ \\
\hline 42 & No & No & Stool; Ritchie method & Logistic regression & $\begin{array}{c}\text { Strongyloides at } 30 \text { months is associated with decreased head } \\
\text { circumference }(p=0.002)\end{array}$ \\
\hline 43 & No & No & Stool; Kato-Katz method & Logistic regression & No relationship between Strongyloides and anaemia \\
\hline 44 & No & No & Stool; Kato-Katz method & Logistic regression & $\begin{array}{c}\text { Negative impact on language function of infants }(p<0.05) \\
\text { Non-significant impact on gross motor, sociocognition, and self-care }\end{array}$ \\
\hline 45 & No & Yes & Stool; not specified & Chi-square test & No relationship to anaemia \\
\hline 46 & No & No & $\begin{array}{l}\text { Stool; Baermann and } \\
\text { Kato-Katz methods }\end{array}$ & $\begin{array}{l}\text { Multivariate logistic } \\
\text { regression }\end{array}$ & $\begin{array}{l}\text { No relationship to anaemia } \\
\text { Non-significant relationship between weight-for-age and BMI-for-age }\end{array}$ \\
\hline 47 & No & No & Not specified & $\begin{array}{l}\text { Multivariate logistic } \\
\text { regression }\end{array}$ & $\begin{array}{l}\text { Increased risk of IUGR } \\
\text { Malnourished women with Strongyloides most at risk }\end{array}$ \\
\hline 48 & No & No & Stool; Baermann method & Chi-square and $t$-test & $\begin{array}{l}\text { Malaria co-infection had higher rates of pre-term delivery, } \\
\text { small-for-gestational-age, and LBW }(p<0.05)\end{array}$ \\
\hline
\end{tabular}


Table 6. Anthropometric changes associated with S. stercoralis infections.

\begin{tabular}{ccccc}
\hline Study & Weight-for-Age z-Score & Weight-for-Height z-Score & Height-for-Age z-Score & Head Circumference z-Score \\
\hline 39 & NR & $-1.01(p=$ NS) & $-2.03(p<0.01)$ & NR \\
\hline 40 & Positive association $(p=0.045)$ & NR & No association $(p=0.24)$ & NR \\
\hline 41 & No association & No association & No association & NR \\
\hline 42 & No association & No association & No association & $-1.69(p=0.002)$ at 30 months \\
\hline 43 & NR & $-0.24(p=$ NS $)$ & NR & NR \\
\hline \multicolumn{7}{c}{ NR: not reported. }
\end{tabular}

Generally, consensus from the studies was that malnutrition either predisposes participants to $S$. stercoralis infections or chronic strongyloidiasis may cause malnutrition. Due to their study designs, firm conclusions could not be made to determine whether strongyloidiasis is a risk factor or consequence of malnutrition. This issue becomes further complicated when considering that strongyloidiasis was seen more commonly in populations of lower socio-economic status, as malnutrition is also more commonly observed in these groups.

\subsection{Strongyloidiasis and Anaemia}

Five studies measured whether S. stercoralis contributed to maternal anaemia $[33,35,43,45,46]$. One study found that helminth infections were a predictor of iron-deficiency anaemia. However, the helminths were not differentiated in the results so conclusions cannot be made about the effects of S. stercoralis [33]. The other four studies found no relationship between strongyloidiasis and anaemia.

\subsection{Case Reports}

Four case reports were found as part of the literature search that fulfilled our inclusion criteria (Table 7) [49-52]. All four cases describe women who presented at varying stages of gestation with predominantly gastrointestinal or respiratory symptoms. Two cases were classified as HS, one as DS, and one was symptomatic but non-disseminated. Corticosteroids preceded two of the cases, and in both of these cases the patients were found to have either HS or DS. Two women had HTLV-1 co-infections, which has been previously noted as a common occurrence. Two women required ICU admissions, and one patient died from cardiorespiratory arrest secondary to septic shock. Fetal demise also occurred in the patient who passed away [48].

All patients were treated with ivermectin. Of the three women who survived, all underwent spontaneous vaginal births to healthy babies, with no complications. They made a full recovery from the infection, although one mother re-presented a year later, again pregnant and suffering from gastrointestinal symptoms [50]. She was found to have been re-infected with S. stercoralis. 
Table 7. Summary of case reports.

\begin{tabular}{|c|c|c|c|c|c|c|}
\hline $\begin{array}{l}\text { Author, Year, } \\
\text { Country }\end{array}$ & $\begin{array}{c}\text { Country of Origin, } \\
\text { Gestation }\end{array}$ & Presenting Complaint & HS or DS? & $\begin{array}{l}\text { Corticosteroids } \\
\text { Administered }\end{array}$ & Treatment & Outcome \\
\hline $\begin{array}{l}\text { Buresch et al., 2015, } \\
\text { USA [49] }\end{array}$ & Haiti, 25 weeks & $\begin{array}{l}\text { Chest pain, dyspnoea, } \\
\text { copious bilious vomiting }\end{array}$ & HS & $\begin{array}{l}\text { Betamethasone } 12 \mathrm{mg}, \\
2 \text { doses } 24 \text { h apart }\end{array}$ & Ivermectin & $\begin{array}{l}\text { Septic shock, SIRS, } \\
\text { cardiopulmonary } \\
\text { arrest, fetal demise }\end{array}$ \\
\hline $\begin{array}{l}\text { Heaton et al., 2002, } \\
\text { USA [52] }\end{array}$ & Ethiopia, 9 weeks & $\begin{array}{c}\text { Diarrhoea, epigastric pain, } \\
\text { vomiting }\end{array}$ & None & None & Ivermectin $200 \mu \mathrm{g} / \mathrm{kg}$ & $\begin{array}{c}\text { SVB at term, } \\
\text { cleared of infection }\end{array}$ \\
\hline $\begin{array}{c}\text { Malézieux-Picard } \\
\text { et al., 2016, } \\
\text { France [50] }\end{array}$ & $\begin{array}{l}\text { Burkina Faso, } \\
32 \text { weeks }\end{array}$ & $\begin{array}{l}\text { Abdominal pain, anorexia, } \\
\text { constipation, weight loss }\end{array}$ & HS & $\begin{array}{l}\text { Betamethasone } \\
12 \mathrm{mg} \text { stat }\end{array}$ & $\begin{array}{l}\text { Ivermectin } \\
200 \mu \mathrm{g} / \mathrm{kg} / \text { day } \\
\text { for } 3 \text { days }\end{array}$ & $\begin{array}{l}\text { SVB, recovered from } \\
\text { infection }\end{array}$ \\
\hline $\begin{array}{l}\text { Prasad et al., 2016, } \\
\text { India [51] }\end{array}$ & India, 39 weeks & Cough, watery diarrhoea & DS & None & Ivermectin $12 \mathrm{mg}$ & $\begin{array}{l}\text { SVB, cleared of } \\
\text { infection }\end{array}$ \\
\hline
\end{tabular}




\section{Discussion}

This review aimed to summarise current literature that analysed the long-term health outcomes of strongyloidiasis on pregnant women, their offspring, and children. Our findings suggest that there are enduring consequences for children that are either born to infected mothers, or who are chronically infected early in their development. To our knowledge, this is the first systematic literature review that attempts to determine the possibility of chronic health effects caused by strongyloidiasis in these subgroups.

The small number of studies that investigated the birth outcomes of newborns with infected mothers found that there is an association between strongyloidiasis and LBW. The 95\% confidence intervals of these studies were large, despite always showing positive associations with LBW. Research has consistently recognised LBW to have lasting impacts on the morbidity and mortality of these newborns, as per the Barker and Brenner hypotheses [53]. The reliability of strongyloidiasis causing LBW is still questionable, as studies were conducted in developing countries with participants that had a range of other comorbidities (such as HIV). Therefore, further research and analysis of this potential risk factor is required. If strongyloidiasis is confirmed to cause LBW, the infection should be treated like other known risk factors for LBW, and women should receive appropriate prenatal screening and treatment [54].

Studies that measured the anthropometry of infected infants and children generally agreed that strongyloidiasis did result in a negative impact on their growth. Wasting and stunting are long-term detriments to the wellbeing of children, and research has established that they lead to increased medical comorbidities, reduced schooling, and reduced economic productivity $[55,56]$. The main effects of strongyloidiasis were only seen in the more acute measurement of wasting, rather than the more chronic indicator of stunting, thus the clinical implications of this finding are less certain. However, a study conducted by Richard et al. found that wasting was associated with stunting and the long-term effects that go with this [57]. Therefore, strongyloidiasis is likely to have clinically significant impacts on the health of people infected during childhood. Ivermectin should be used as part of existing community and school-based deworming initiatives in endemic areas, to prevent the enduring consequences of wasting.

The assessment of strongyloidiasis affecting the growth of children is affected by the small number of included articles that commented on these measurements. Studies also did not publish their full results lists, and the differences in cohort characteristics were large. Epidemiologically, the studies were unable to determine if strongyloidiasis was more common in malnourished children or if the disease process itself caused malnutrition. As the studies were cross-sectional, no studies looked at whether children had been chronically infected with strongyloidiasis. In order to confidently conclude that S. stercoralis does in fact cause deficiencies in growth and therefore have direct clinical consequences, longitudinal studies of affected participants with larger sample sizes need to be performed.

Several studies noted a range of common epidemiological risk factors which may lead to a greater risk of infants and pregnant women contracting this infection. Absence of footwear, other household members already being infected, and poor sanitation facilities, were all emphasised in the studies as potential risk factors. This poses another challenge to public health strategies, as newborns can quickly become chronically infested from their mothers or family members. Even if strongyloidiasis does not cause LBW, maternal infection can still cause chronic health effects due to the high likelihood of passing on their infection early in childhood and causing malnutrition, wasting or stunting. Interventions targeting water, sanitation, and hygiene (WASH) may provide a solution to reducing these epidemiological risk factors and therefore the long-term consequences of strongyloidiasis [58].

Based on the review findings, anaemia should not be considered a potential complication of S. stercoralis infections. This is in contrast to other helminths such as hookworm, which have been more strongly linked with anaemia [59]. Studies that have observed the clinical manifestations of strongyloidiasis in different cohorts have produced conflicting results regarding anaemia $[60,61]$. The primary reason why we are still not sure whether S. stercoralis causes anaemia is because both are 
typically common in under-nourished, socio-economically poorer populations with increased health comorbidities. This makes the task of attributing anaemia to the helminth difficult.

There is a paucity in literature looking at the effects of $S$. stercoralis infection on pregnant women, their offspring, and infected children. The only literature that could be found that mentions pregnant women with severe infection were case studies; no prospective studies could be found in which pregnancy was researched as a potential risk factor of HS or DS. Likewise, very little information currently exists to determine whether $S$. stercoralis infection in the mother is an independent risk factor for LBW, SGA, IUGR, or preterm delivery. As there were so few studies found analysing these variables, this may suggest a publication bias is present which has inflated the health effects strongyloidiasis has on these populations.

Although only a few case reports exist that discuss strongyloidiasis in pregnancy, the ones found in this review showed that this infection can cause severe or ultimately fatal complications. Pregnant women are already immunosuppressed and thus may be at a higher risk of hyperinfection syndrome. Clinicians must currently rely on individual cases for information on the possible disease course of strongyloidiasis or look elsewhere to different population groups. Corticosteroids preceded $50 \%$ of the onset of HS, although the sample was small. In areas endemic to S. stercoralis, women giving preterm birth or who are immunosuppressed are at risk of these severe complications and should be screened accordingly.

There is reason to believe that the prevalence and therefore the health effects of strongyloidiasis is underestimated in the current literature. The majority of studies only included S. stercoralis as one of many parasites tested. As the researchers were not directly focusing on strongyloidiasis they accordingly did not use accurate diagnostic tests and therefore are likely to have missed a significant amount of S. stercoralis infections in their participants. Even amongst stool samples, the gold standard of seven serial samples was not performed [1]. This may have had the potential to understate the longitudinal consequences strongyloidiasis had on children and thereby prevented studies from achieving statistical significance. This failure to achieve significance and the substantially low prevalence data compared to other helminths may have resulted in unpublished data, creating a relative publication bias in the literature reviewed. Healthcare providers would benefit from more accurate prevalence data in order to appropriately manage these subgroups. Therefore, the convenient and reliable serological tests should be used in further studies on strongyloidiasis.

If strongyloidiasis does indeed lead to adverse health effects in infants, this has direct clinical implications for endemic areas. This review strengthens arguments for increased screening and treatment of pregnant women to confer the best possible outcome for their children. Ivermectin has been proven to be safe in pregnancy, despite not currently being used due to its assigned pregnancy category of B3 [62]. The clinicians in all four case reports used ivermectin and no complications were observed. It is the opinion of the authors that there is enough favourable evidence to support the use of ivermectin in pregnancy, particularly given the significance of the consequences to mothers and children. Health practitioners in endemic areas would benefit from further clarification of whether this drug is appropriate for use in pregnant women.

The findings outlined in this review need to be considered with caution, as only a small number of studies have currently looked at these effects and their methodological quality may be considered suboptimal. While some studies did achieve statistical significance in their findings, they often occurred in small samples, in participants with comorbidities such as HIV or malnutrition, and in countries in developing nations; thus, their findings cannot be generalised.

\section{Limitations}

A number of limitations to this review have been identified and must be taken into consideration when analysing the findings. Studies reviewed used varying methods of statistical analysis, which were presented and compared despite some results not being statistically significant or insufficiently powered. Many studies were conducted decades ago in vastly different contexts, using less accurate 
testing methods. It was unfortunate that some studies aggregated the results of $S$. stercoralis with other helminths such as hookworm; these were still included in the review. A significant proportion of our included full-texts also could not be found. Meta-analysis could not be performed and thus only simple pooling of results was possible. Due to the marked variation in the outcomes assessed by different studies, the findings were compared between cohorts that varied dramatically in their characteristics. Because of these limitations, a level of bias in the findings was unavoidable, despite taking steps to ensure transparency and academic rigour.

\section{Conclusions}

In conclusion, current research is suggestive that maternal strongyloidiasis is a risk factor for LBW. However, a lack of literature and sub-optimal study designs prevents this from being a certainty. Chronic infection in childhood is most strongly associated with wasting and may potentially lead to stunting. Due to similar issues, current research is unable to ascertain whether strongyloidiasis leads to malnutrition or is just more commonly found in the malnourished. The strongest conclusion gleaned from this literature review was that the prevalence of strongyloidiasis was very likely underestimated, due to the methods of testing and lack of focus on this specific helminth in the study designs. In order to truly determine whether pregnant women, their offspring, and infected children are in fact susceptible sub-groups of the population, further longitudinal research utilising modern serological techniques and control groups is required.

Funding: This research received no external funding.

Acknowledgments: We are grateful to Caroline de Costa and Robyn McDermott for their support in producing this review. This paper is dedicated to the memory of Emeritus Professor Rick Speare. His contributions to the field of parasitology are an inspiration that will continue to guide future researchers for years to come.

Conflicts of Interest: The authors declare no conflict of interest. 


\section{Appendix A}

\begin{tabular}{|c|c|c|c|}
\hline Section/topic & $\#$ & Checklist item & $\begin{array}{l}\text { Reported } \\
\text { on page \# }\end{array}$ \\
\hline \multicolumn{4}{|l|}{ TITLE } \\
\hline Title & 1 & Identify the report as a systematic review, meta-analysis, or both. & 1 \\
\hline \multicolumn{4}{|l|}{ ABSTRACT } \\
\hline Structured summary & 2 & $\begin{array}{l}\text { Provide a structured summary including, as applicable: background; objectives; data sources; study eligibility criteria, } \\
\text { participants, and interventions; study appraisal and synthesis methods; results; limitations; conclusions and } \\
\text { implications of key findings; systematic review registration number. }\end{array}$ & 1 \\
\hline \multicolumn{4}{|l|}{ INTRODUCTION } \\
\hline Rationale & 3 & Describe the rationale for the review in the context of what is already known. & 2 \\
\hline Objectives & 4 & $\begin{array}{l}\text { Provide an explicit statement of questions being addressed with reference to participants, interventions, comparisons, } \\
\text { outcomes, and study design (PICOS). }\end{array}$ & 3 \\
\hline \multicolumn{4}{|l|}{ METHODS } \\
\hline Protocol and registration & 5 & $\begin{array}{l}\text { Indicate if a review protocol exists, if and where it can be accessed (e.g., Web address), and, if available, provide } \\
\text { registration information including registration number. }\end{array}$ & 3 \\
\hline Eligibility criteria & 6 & $\begin{array}{l}\text { Specify study characteristics (e.g., PICOS, length of follow-up) and report characteristics (e.g., years considered, } \\
\text { language, publication status) used as criteria for eligibility, giving rationale. }\end{array}$ & 3 \\
\hline Information sources & 7 & $\begin{array}{l}\text { Describe all information sources (e.g., databases with dates of coverage, contact with study authors to identify } \\
\text { additional studies) in the search and date last searched. }\end{array}$ & 3 \\
\hline Search & 8 & $\begin{array}{l}\text { Present full electronic search strategy for at least one database, including any limits used, such that it could be } \\
\text { repeated. }\end{array}$ & 4 \\
\hline Study selection & 9 & $\begin{array}{l}\text { State the process for selecting studies (i.e., screening, eligibility, included in systematic review, and, if applicable, } \\
\text { included in the meta-analysis). }\end{array}$ & 4 \\
\hline Data collection process & 10 & $\begin{array}{l}\text { Describe method of data extraction from reports (e.g., piloted forms, independently, in duplicate) and any processes } \\
\text { for obtaining and confirming data from investigators. }\end{array}$ & 4 \\
\hline Data items & 11 & $\begin{array}{l}\text { List and define all variables for which data were sought (e.g., PICOS, funding sources) and any assumptions and } \\
\text { simplifications made. }\end{array}$ & 4 \\
\hline $\begin{array}{l}\text { Risk of bias in individual } \\
\text { studies }\end{array}$ & 12 & $\begin{array}{l}\text { Describe methods used for assessing risk of bias of individual studies (including specification of whether this was } \\
\text { done at the study or outcome level), and how this information is to be used in any data synthesis. }\end{array}$ & 5 \\
\hline Summary measures & 13 & State the principal summary measures (e.g., risk ratio, difference in means). & 4 \\
\hline Synthesis of results & 14 & $\begin{array}{l}\text { Describe the methods of handling data and combining results of studies, if done, including measures of consistency } \\
\left(e . \text { e., }^{2} \text { ) for each meta-analysis. }\right.\end{array}$ & 4 \\
\hline
\end{tabular}

Figure A1. Cont. 


\begin{tabular}{|c|c|c|c|}
\hline Section/topic & $\#$ & Checklist item & $\begin{array}{l}\text { Reported } \\
\text { on page \# }\end{array}$ \\
\hline Risk of bias across studies & 15 & $\begin{array}{l}\text { Specify any assessment of risk of bias that may affect the cumulative evidence (e.g., publication bias, selective } \\
\text { reporting within studies). }\end{array}$ & 5 \\
\hline Additional analyses & 16 & $\begin{array}{l}\text { Describe methods of additional analyses (e.g., sensitivity or subgroup analyses, meta-regression), if done, indicating } \\
\text { which were pre-specified. }\end{array}$ & $\mathrm{N} / \mathrm{A}$ \\
\hline \multicolumn{4}{|l|}{ RESULTS } \\
\hline Study selection & 17 & $\begin{array}{l}\text { Give numbers of studies screened, assessed for eligibility, and included in the review, with reasons for exclusions at } \\
\text { each stage, ideally with a flow diagram. }\end{array}$ & 6 \\
\hline Study characteristics & 18 & $\begin{array}{l}\text { For each study, present characteristics for which data were extracted (e.g., study size, PICOS, follow-up period) and } \\
\text { provide the citations. }\end{array}$ & 9 \\
\hline Risk of bias within studies & 19 & Present data on risk of bias of each study and, if available, any outcome level assessment (see item 12). & 8 \\
\hline Results of individual studies & 20 & $\begin{array}{l}\text { For all outcomes considered (benefits or harms), present, for each study: (a) simple summary data for each } \\
\text { intervention group (b) effect estimates and confidence intervals, ideally with a forest plot. }\end{array}$ & 6 \\
\hline Synthesis of results & 21 & Present results of each meta-analysis done, including confidence intervals and measures of consistency. & $\mathrm{N} / \mathrm{A}$ \\
\hline Risk of bias across studies & 22 & Present results of any assessment of risk of bias across studies (see Item 15). & 8 \\
\hline Additional analysis & 23 & Give results of additional analyses, if done (e.g., sensitivity or subgroup analyses, meta-regression [see Item 16]). & $\mathrm{N} / \mathrm{A}$ \\
\hline \multicolumn{4}{|l|}{ DISCUSSION } \\
\hline Summary of evidence & 24 & $\begin{array}{l}\text { Summarize the main findings including the strength of evidence for each main outcome; consider their relevance to } \\
\text { key groups (e.g., healthcare providers, users, and policy makers). }\end{array}$ & 11 \\
\hline Limitations & 25 & $\begin{array}{l}\text { Discuss limitations at study and outcome level (e.g., risk of bias), and at review-level (e.g., incomplete retrieval of } \\
\text { identified research, reporting bias). }\end{array}$ & 13 \\
\hline Conclusions & 26 & Provide a general interpretation of the results in the context of other evidence, and implications for future research. & 14 \\
\hline \multicolumn{4}{|l|}{ FUNDING } \\
\hline Funding & 27 & $\begin{array}{l}\text { Describe sources of funding for the systematic review and other support (e.g., supply of data); role of funders for the } \\
\text { systematic review. }\end{array}$ & 14 \\
\hline
\end{tabular}

Figure A1. Preferred Reporting Items for Systematic Reviews and Meta-Analyses (PRISMA) checklist. 


\section{Appendix B}
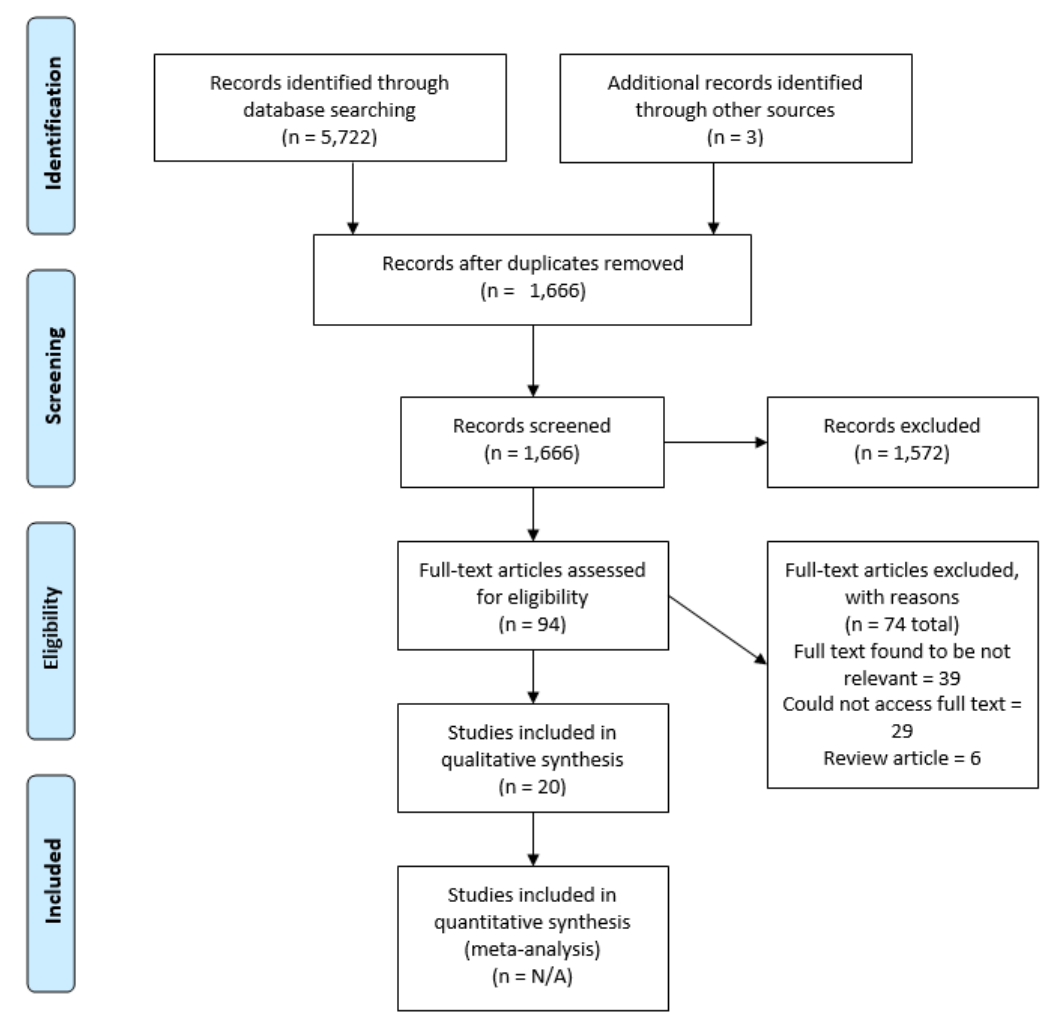

Figure A2. PRISMA flow diagram.

Appendix C

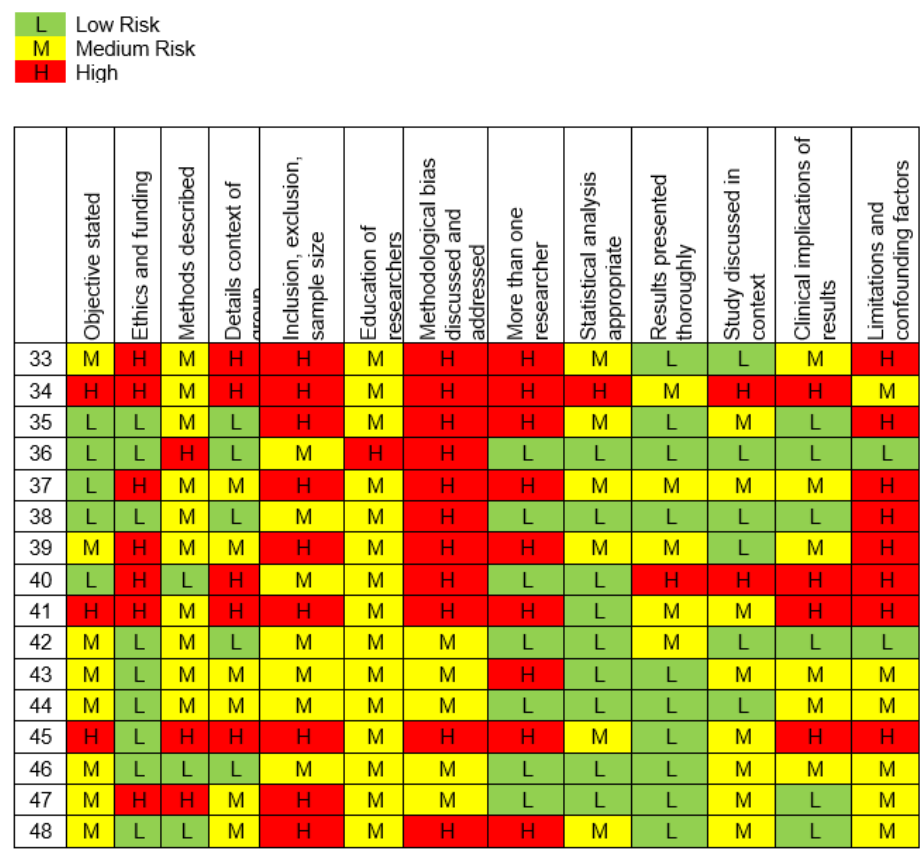

Figure A3. Quality assessment scale. 
Y Yes

NA Not Applicable

No

\begin{tabular}{|c|c|c|c|c|c|c|c|c|}
\hline & 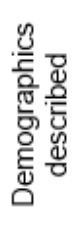 & 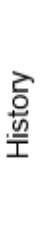 & 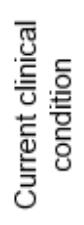 & 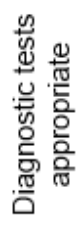 & 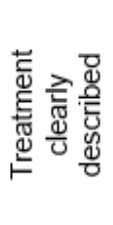 & 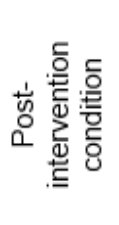 & 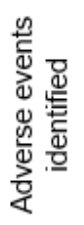 & 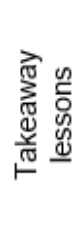 \\
\hline 49 & $\bar{Y}$ & $Y$ & $Y$ & $Y$ & $\bar{Y}$ & $\bar{Y}$ & $Y$ & $\bar{Y}$ \\
\hline 50 & $\mathrm{Y}$ & $Y$ & $Y$ & $\bar{Y}$ & $Y$ & $\mathrm{~N}$ & NA & $\bar{Y}$ \\
\hline 50 & $\mathrm{Y}$ & $\mathrm{Y}$ & $\mathrm{Y}$ & $\mathrm{Y}$ & $\mathrm{Y}$ & $\mathrm{Y}$ & $\mathrm{Y}$ & $\mathrm{Y}$ \\
\hline 51 & $\bar{Y}$ & $\mathrm{Y}$ & $\bar{Y}$ & $\bar{Y}$ & $\bar{Y}$ & $\mathrm{~N}$ & NA & $\bar{Y}$ \\
\hline
\end{tabular}

Figure A4. Quality assessment according to JBI Critical Appraisal Tool: Checklist for Case Reports.

\section{References}

1. Bisoffi, Z.; Buonfrate, D.; Montresor, A.; Requena-Méndez, A.; Muñoz, J.; Krolewiecki, A.J.; Gotuzzo, E.; Mena, M.A.; Chiodini, P.L.; Anselmi, M.; et al. Strongyloides stercoralis: A plea for action. PLoS Negl. Trop. Dis. 2013, 7, e2214. [CrossRef] [PubMed]

2. Puthiyakunnon, S.; Boddu, S.; Li, Y.; Zhou, X.; Wang, C.; Li, J.; Chen, X. Strongyloidiasis-An insight into its global prevalence and management. PLoS Negl. Trop. Dis. 2014, 8, e3018. [CrossRef] [PubMed]

3. Caumes, E.; Keystone, J.S. Acute strongyloidiasis: A rarity. Chronic strongyloidiasis: A time bomb! J. Travel Med. 2011, 18, 71-72. [CrossRef] [PubMed]

4. Grove, D.I. Human strongyloidiasis. Adv. Parasitol. 1996, 38, 251-309. [PubMed]

5. Siddiqui, A.A.; Berk, S.L. Diagnosis of Strongyloides stercoralis infection. Clin. Infect. Dis. 2001, 33, $1040-1047$. [CrossRef] [PubMed]

6. Requena-Méndez, A.; Chiodini, P.; Bisoffi, Z.; Buonfrate, D.; Gotuzzo, E.; Muñoz, J. The laboratory diagnosis and follow up of strongyloidiasis: A systematic review. PLoS Negl. Trop. Dis. 2013, 7, e2002. [CrossRef] [PubMed]

7. Centers for Disease Control. Resources for Health Professionals. Strongyloidiasis Website. Published 2016. Updated 19 August 2017. Available online: https://www.cdc.gov/parasites/strongyloides/health_ professionals/index.html (accessed on 27 August 2017).

8. Shield, J.M.; Page, W. Effective diagnostic tests and anthelmintic treatment for Strongyloides stercoralis make community control feasible. P. N. G. Med. J. 2008, 51, 105-119. [PubMed]

9. Mejia, R.; Nutman, T.B. Screening, prevention, and treatment for hyperinfection syndrome and disseminated infections caused by Strongyloides stercoralis. Curr. Opin. Infect. Dis. 2012, 25, 458-463. [CrossRef] [PubMed]

10. Kassalik, M.; Mönkemüller, K. Strongyloides stercoralis Hyperinfection syndrome and disseminated disease. Gastroenterol. Hepatol. 2011, 7, 766-768.

11. Milner, P.; Irvine, R.; Barton, C.; Bras, G.; Richards, R. Intestinal malabsorption in Strongyloides stercoralis infestation. Gut 1965, 6, 574. [CrossRef] [PubMed]

12. Kotcher, E.; Miranda, M.; Esquivel, R.; Peña-Chavarría, A.; Donohugh, D.L.; Baldizón, C.; Acosta, A.; Apuy, J.L. Intestinal malabsorption and helminthic and protozoan infections of the small intestine. Gastroenterology 1966, 50, 366-371. [PubMed]

13. Robinson, D.P.; Klein, S.L. Pregnancy and pregnancy-associated hormones alter immune responses and disease pathogenesis. Horm. Behav. 2012, 62, 263-271. [CrossRef] [PubMed]

14. Mor, G.; Cardenas, I. The immune system in pregnancy: A unique complexity. Am. J. Reprod. Immunol. 2010, 63, 425-433. [CrossRef] [PubMed]

15. Roberts, D.; Dalziel, S. Antenatal corticosteroids for accelerating fetal lung maturation for women at risk of preterm birth. Cochrane Database Syst. Rev. 2006. [CrossRef]

16. McClure, E.M.; Meshnick, S.R.; Mungai, P.; Malhotra, I.; King, C.L.; Goldenberg, R.L.; Hudgens, M.G.; Siega-Riz, A.M.; Dent, A.E. The association of parasitic infections in pregnancy and maternal and fetal anemia: A cohort study in coastal Kenya. PLoS Negl. Trop. Dis. 2014, 8, e2724. [CrossRef] [PubMed] 
17. Tay, S.C.K.; Nani, E.A.; Walana, W. Parasitic infections and maternal anaemia among expectant mothers in the Dangme East District of Ghana. BMC Res. Notes 2017, 10, 3. [CrossRef] [PubMed]

18. Aderoba, A.K.; Iribhogbe, O.I.; Olagbuji, B.N.; Olokor, O.E.; Ojide, C.K.; Ande, A.B. Prevalence of helminth infestation during pregnancy and its association with maternal anemia and low birth weight. Int. J. Gynaecol. Obstet. 2015, 129, 199-202. [CrossRef] [PubMed]

19. Salam, R.A.; Haider, B.A.; Humayun, Q.; Bhutta, Z.A. Effect of administration of antihelminthics for soil-transmitted helminths during pregnancy. Cochrane Database Syst. Rev. 2015. [CrossRef] [PubMed]

20. Imhoff-Kunsch, B.; Briggs, V. Antihelminthics in pregnancy and maternal, newborn and child health. Paediatr. Perinat. Epidemiol. 2012, 26 (Suppl. S1), 223-238. [CrossRef] [PubMed]

21. Fairley, J.K.; Bisanzio, D.; King, C.H.; Kitron, U.; Mungai, P.; Muchiri, E.; King, C.L.; Malhotra, I. Birthweight in offspring of mothers with high prevalence of helminth and malaria infection in coastal Kenya. Am. J. Trop. Med. Hyg. 2013, 88, 48-53. [CrossRef] [PubMed]

22. Prendergast, A.J.; Humphrey, J.H. The stunting syndrome in developing countries. Paediatr. Int. Child Health 2014, 34, 250-265. [CrossRef] [PubMed]

23. Martins, V.J.B.; Toledo Florêncio, T.M.M.; Grillo, L.P.; do Carmo P Franco, M.; Martins, P.A.; Clemente, A.P.; Santos, C.D.; de Fatima A Vieira, M.; Sawaya, A.L. Long-lasting effects of undernutrition. Int. J. Environ. Res. Public Health 2011, 8, 1817-1846. [CrossRef] [PubMed]

24. Moher, D.; Liberati, A.; Tetzlaff, J.; Altman, D.G.; The PRISMA Group. Preferred Reporting Items for Systematic Reviews and Meta-Analyses: The PRISMA Statement. PLoS Med. 2009, 6, e1000097. [CrossRef] [PubMed]

25. Mays, N.; Pope, C.; Popay, J. Systematically reviewing qualitative and quantitative evidence to inform management and policy-making in the health field. J. Health Serv. Res. Policy 2005, 10 (Suppl. S1), 6-20. [CrossRef] [PubMed]

26. Buonfrate, D.; Requena-Mendez, A.; Angheben, A.; Muñoz, J.; Gobbi, F.; Van Den Ende, J.; Bisoffi, Z. Severe strongyloidiasis: A systematic review of case reports. BMC Infect. Dis. 2013, 13, 78. [CrossRef] [PubMed]

27. Miller, A.; Smith, M.L.; Judd, J.A.; Speare, R. Strongyloides stercoralis: Systematic review of barriers to controlling strongyloidiasis for Australian Indigenous communities. PLoS Negl. Trop. Dis. 2014, 8, e3141. [CrossRef] [PubMed]

28. Smith, T.O.; Nichols, R.; Gilding, E.; Donell, S.T. Are location, proportion and length of VM patellar attachment aetiological factors in patellofemoral dysfunction? A systematic review. Eur. J. Orthop. Surg. Traumatol. 2009, 19, 63-73. [CrossRef]

29. Hu, A.S.Y.; Menon, R.; Gunnarsson, R.; de Costa, A. Risk factors for conversion of laparoscopic cholecystectomy to open surgery-A systematic literature review of 30 studies. Am. J. Surg.. [CrossRef] [PubMed]

30. Lo, C.K.-L.; Mertz, D.; Loeb, M. Newcastle-Ottawa Scale: Comparing reviewers' to authors' assessments. BMC Med. Res. Methodol. 2014, 14, 45. [CrossRef] [PubMed]

31. Wilke, J.; Krause, F.; Niederer, D.; Engeroff, T.; Nürnberger, F.; Vogt, L.; Banzer, W. Appraising the methodological quality of cadaveric studies: Validation of the QUACS scale. J. Anat. 2015, 226, 440-446. [CrossRef] [PubMed]

32. The Joanna Briggs Institute. Checklist for Case Reports. Critical Appraisal Tools Website. Published 2017. Available online: http:/ /joannabriggs.org/research/critical-appraisal-tools.html (accessed on 27 August 2017).

33. Baidoo, S.; Tay, S.; Obiri-Danso, K.; Abruquah, H. Intestinal helminth infection and anaemia during pregnancy: A community based study in Ghana. Afr. J. Bacteriol. Res. 2010, 2, 9-13.

34. Barnish, G.; Harari, M. Possible effects of Strongyloides fuelleborni-like infections on children in the Karimui area of Simbu Province. P. N. G. Med. J. 1989, 32, 51-54. [PubMed]

35. Cabada, M.M.; Lopez, M.; Arque, E.; White, A.C. Prevalence of soil-transmitted helminths after mass albendazole administration in an indigenous community of the Manu jungle in Peru. Pathog. Glob. Health 2014, 108, 200-205. [CrossRef] [PubMed]

36. Chiang Mai Low Birth Weight Study Group; Mangklabruks, A.; Rerkasem, A.; Wongthanee, A.; Rerkasem, K.; Chiowanich, P.; Sritara, P.; Pruenglampoo, S.; Yipintsoi, T.; Tongsong, T.; et al. The risk factors of low birth weight infants in the northern part of Thailand. J. Med. Assoc. Thail. 2012, 95, 358-365. [PubMed]

37. Dada-Adegbola, H.O.; Bakare, R.A. Strongyloidiasis in children five years and below. West Afr. J. Med. 2004, 23, 194-197. [CrossRef] [PubMed] 
38. Dreyfuss, M.L.; Msamanga, G.I.; Spiegelman, D.; Hunter, D.J.; Urassa, E.J.; Hertzmark, E.; Fawzi, W.W. Determinants of low birth weight among HIV-infected pregnant women in Tanzania. Am. J. Clin. Nutr. 2001, 74, 814-826. [CrossRef] [PubMed]

39. Egger, R.J.; Hofhuis, E.H.; Bloem, M.W.; Chusilp, K.; Wedel, M.; Intarakhao, C.; Saowakontha, S.; Schreurs, W.H. Association between intestinal parasitoses and nutritional status in 3-8-year-old children in northeast Thailand. Trop. Geogr. Med. 1990, 42, 312-323. [PubMed]

40. Herrera, J.; Marcos, L.; Terashima, A.; Alvarez, H.; Samalvides, F.; Gotuzzo, E. Factors associated with Strongyloides stercoralis infection in an endemic area in Peru. Rev. Gastroenterol. Peru 2006, 26, 357-362. [PubMed]

41. King, S.E.; Mascie-Taylor, C. 'Strongyloides fuelleborni kellyi' and other intestinal helminths in children from Papua New Guinea: Associations with nutritional status and socioeconomic factors. P. N. G. Med. J. 2004, 47, 181-191. [PubMed]

42. LaBeaud, A.D.; Nayakwadi Singer, M.; McKibben, M.; Mungai, P.; Muchiri, E.M.; McKibben, E.; Gildengorin, G.; Sutherland, L.J.; King, C.H.; King, C.L.; et al. Parasitism in children aged three years and under: Relationship between infection and growth in rural coastal Kenya. PLoS Negl. Trop. Dis. 2015, 9, e0003721. [CrossRef] [PubMed]

43. Muhangi, L.; Woodburn, P.; Omara, M.; Omoding, N.; Kizito, D.; Mpairwe, H.; Nabulime, J.; Ameke, C.; Morison, L.A.; Elliott, A.M. Associations between mild-to-moderate anaemia in pregnancy and helminth, malaria and HIV infection in Entebbe, Uganda. Trans. R. Soc. Trop. Med. Hyg. 2007, 101, 899-907. [CrossRef] [PubMed]

44. Nampijja, M.; Apule, B.; Lule, S.; Akurut, H.; Muhangi, L.; Webb, E.L.; Lewis, C.; Elliott, A.M.; Alcock, K.J. Effects of maternal worm infections and anthelminthic treatment during pregnancy on infant motor and neurocognitive functioning. J. Int. Neuropsychol. Soc. 2012, 18, 1019-1030. [CrossRef] [PubMed]

45. Phuanukoonnon, S.; Michael, A.; Kirarock, W.S.; Pomat, W.S.; van den Biggelaar, A.H. Intestinal parasitic infections and anaemia among pregnant women in the highlands of Papua New Guinea. P. N. G. Med. J. 2013, 56, 119-125. [PubMed]

46. Verhagen, L.M.; Incani, R.N.; Franco, C.R.; Ugarte, A.; Cadenas, Y.; Sierra Ruiz, C.I.; Hermans, P.W.; Hoek, D.; Campos Ponce, M.; de Waard, J.H.; et al. High malnutrition rate in Venezuelan Yanomami compared to Warao Amerindians and Creoles: Significant associations with intestinal parasites and anemia. PLoS ONE 2013, 8, e77581. [CrossRef] [PubMed]

47. Villar, J.; Klebanoff, M.; Kestler, E. The effect on fetal growth of protozoan and helminthic infection during pregnancy. Obstet. Gynecol. 1989, 74, 915-920. [PubMed]

48. Yatich, N.J.; Jolly, P.E.; Funkhouser, E.; Agbenyega, T.; Rayner, J.C.; Ehiri, J.E.; Turpin, A.; Stiles, J.K.; Ellis, W.O.; Jiang, Y.; et al. The effect of malaria and intestinal helminth coinfection on birth outcomes in Kumasi, Ghana. Am. J. Trop. Med. Hyg. 2010, 82, 28-34. [CrossRef] [PubMed]

49. Buresch, A.M.; Judge, N.E.; Dayal, A.K.; Garry, D.J. A fatal case of strongyloidiasis in pregnancy. Obstet. Gynecol. 2015, 126, 87-89. [CrossRef] [PubMed]

50. Malezieux-Picard, A.; Saint-Paul, M.C.; Dellamonica, J.; Courjon, J.; Tieulié, N.; Marty, P.; Fuzibet, J.G.; Collomp, R.; Marinho, J.A.; Queyrel, V. Severe intestinal obstruction due to Strongyloides stercoralis in a pregnant woman. Med. Mal. Infect. 2017, 47, 429-431. [CrossRef] [PubMed]

51. Prasad, M.; Chauhan, A.; Chamariya, S.; Kuyare, S.; Koticha, A. A case of strongyloidiasis in pregnancy. 2017, 6, 1130-1131. [CrossRef]

52. Heaton, J.; Shippey, S.; Macri, C.; Macedonia, C. Intestinal helminthes infestation in pregnancy: A case report and literature review. Mil. Med. 2002, 167, 954-955. [PubMed]

53. Reyes, L.; Manalich, R. Long-term consequences of low birth weight. Kidney Int. 2005, 68, S107-S111. [CrossRef] [PubMed]

54. Herceg, A. Improving Health in Aboriginal and Torres Strait Islander Mothers, Babies and Young Children: A Literature Review; Commonwealth Department of Health and Ageing: Canberra, Australia, 2005.

55. Huynh, D.T.T.; Estorninos, E.; Capeding, R.Z.; Oliver, J.S.; Low, Y.L.; Rosales, F.J. Longitudinal growth and health outcomes in nutritionally at-risk children who received long-term nutritional intervention. J. Hum. Nutr. Diet. 2015, 28, 623-635. [CrossRef] [PubMed] 
56. Olofin, I.; McDonald, C.M.; Ezzati, M.; Flaxman, S.; Black, R.E.; Fawzi, W.W.; Caulfield, L.E.; Danaei, G.; Nutrition Impact Model Study (anthropometry cohort pooling). Associations of suboptimal growth with all-cause and cause-specific mortality in children under five years: A pooled analysis of ten prospective studies. PLoS ONE 2013, 8, e64636. [CrossRef] [PubMed]

57. Richard, S.A.; Black, R.E.; Gilman, R.H.; Guerrant, R.L.; Kang, G.; Lanata, C.F.; Mølbak, K.; Rasmussen, Z.A.; Sack, R.B.; Valentiner-Branth, F.; et al. Wasting is associated with stunting in early childhood. J. Nutr. 2012, 142, 1291-1296. [CrossRef] [PubMed]

58. Strunz, E.C.; Addiss, D.G.; Stocks, M.E.; Ogden, S.; Utzinger, J.; Freeman, M.C. Water, sanitation, hygiene, and soil-transmitted helminth infection: A systematic review and meta-analysis. PLoS Med. 2014, 11, e1001620. [CrossRef] [PubMed]

59. Bethony, J.; Brooker, S.; Albonico, M.; Geiger, S.M.; Loukas, A.; Diemert, D.; Hotez, P.J. Soil-transmitted helminth infections: Ascariasis, trichuriasis, and hookworm. Lancet 2006, 367, 1521-1532. [CrossRef]

60. Carrilho, G.F.; Da Costa, G.M.; Olivi, M.J.; Vicentini, V.; Anibal, F.D.F. Anemia in patients with intestinal parasitic infection. Rev. Ibero-Latinoam. Parasitol. 2011, 70, 206-211.

61. Kightlinger, L.K.; Seed, J.R.; Kightlinger, M.B. The epidemiology of Ascaris lumbricoides, Trichuris trichiura, and hookworm in children in the Ranomafana rainforest, Madagascar. J. Parasitol. 1995, 81, 159-169. [CrossRef] [PubMed]

62. Ndyomugyenyi, R.; Kabatereine, N.; Olsen, A.; Magnussen, P. Efficacy of ivermectin and albendazole alone and in combination for treatment of soil-transmitted helminths in pregnancy and adverse events: A randomized open label controlled intervention trial in Masindi district, western Uganda. Am. J. Trop. Med. Hyg. 2008, 79, 856-863. [PubMed]

(C) 2018 by the authors. Licensee MDPI, Basel, Switzerland. This article is an open access article distributed under the terms and conditions of the Creative Commons Attribution (CC BY) license (http://creativecommons.org/licenses/by/4.0/). 